ability and welding techniques for use with selected steels ; and the chemical compatibility of the various materials used in the reactor with the carbon dioxide coolant gas, are some of the other problems being investigated by the Metallurgical Division. A considerable expansion in facilities is planned during 1959, and additional long-term researches relating to uranium, magnesium and the weldability of steel will be started. The design of the best heat transfer surface for the fuel elements is at present largely empirical and at the Heston Research Laboratories two experimental rigs are provided for experimental tests. In both, the fuel element can is placed in a working section and the heat developed in the uranium simulated by an electric heater. Facilities for basic studies in heat transfer and in other design problems have also been set up, and these facilities comprise a flow visualization rig and associated equipment in which water replaces the pressurized carbon dioxide as the working fluid.

Crompton Parkinson, Ltd., the Fairey Aviation Co., Ltd., International Combustion (Holdings), Ltd., Richardsons Westgarth and Co., Ltd., and Nuclear Civil Constructors (Trollope and Colls, Holland and Hannen, and Cubitts) form the five member companies of Atomic Power Constructions, Ltd.

\title{
COFFEE RESEARCH IN THE BELGIAN CONGO
}

$\mathrm{T}$ WO investigations of a fundamental character on the genus Coffea have recently been published by the Institut National pour l'Etude Agronomique du Congo Belge, (i) Recherches sur l'Autostérilité du Caféier Robusta (Coffea canephora Pierre) by M. Devreux, G. Vallaeys, P. Pochet and A. Gilles (No. 78. 1959. Pp. $44+8$ plates. 40 franes); (ii) Recherches sur les Affinités Chromosomiques dans le Genre Coffea by J. Bouharmont (No. 77. Pp. $94+2$ plates. 70 francs). The self-sterility of Robusta coffee has been known in a somewhat confused way for many years, but no convineing demonstration of this phenomenon has previously been presented. This information is important in preparing a rational programme of selection. The investigators of the work indicated above have now shown, under strictly experimental conditions, that this variety is quite self-sterile. As a result of many controlled self-pollination experiments, using 19 clones and based on a very large number of flowers, for example, more than 15,000 in one instance, an extremely small number of fruits has been obtained, the highest percentage not exceeding 0:24. By contrast, when the flowers of the same clones were subjected to cross-pollination, a number of ripe fruits, 30-40 per cent, was obtained. The self-sterility is not attributed

\section{BOTANY IN}

$A^{\mathrm{N}}$ $\mathrm{N}$ agreeable and very well-deserved tribute has been paid to Prof. J. R. Matthews, regius professor of botany in the University of Aberdeen, by his friends, past and present colleagues and former students, on the occasion of his seventieth birthday. During his twenty-five years as regius professor he has greatly increased the stature of his Department, has helped the cause of botanical science by his work on the councils of various societies and has made many valuable contributions to botany, especially in the field of research relating to the origin and distribution of the British flora. The presentation volume under consideration has been printed for the Botanical Society of Edinburgh and appears as a special number of the T'ransactions (38; March 1959. 15s.). There is a foreword by $\mathrm{H}$. R. Fletcher, and, as might perhaps be expected, a number of the articles relate to the ecology of Scottish plants. But there are also some contributions dealing with other aspects of botanical science, for example, "Some Fundamental Considerations on the New Morphology", by H.J.Lam; "Peristome Teeth and Spore Discharge in Mosses", by to defects in floral structure or in micro- or macrosporogenesis but to anomalies in the formation and growth of the pollen-tubes. In no case were these able to traverse the style. While a genetical explanation in terms of ineompatibility may be advanced, validation has still to be obtained.

Observations on the chromosome numbers of thirteen species of Coffea, including all the well-known species such as $C$. arabica, C. liberica, C. stenophylla, etc., have shown that all those examined are diploid with 22 chromosomes, except $C$. arabica which has 44. Certain hybrids are diploid and others tetraploid. The nuclear behaviour at mitosis is apparently identical in all the species. Measurements of chromosome lengths show that these are all much alike. It is considered that these comparisons by measurement confirm the close systematic relation of certain species, but it does not enable a general classification of the genus to be established. An average idiogramme of the African Coffea has been prepared. The author concludes that the genus is a very homogeneous one, and that the species investigated are closely related from the cytological point of view. Lastly, this investigation has yielded no evidence of difficulties in obtaining interspecific hybrids.

\section{SCOTLAND}

C. T. Ingold ; a biographical essay on "The Rev. John Walker (1731-1804)-a Notable Scottish Naturalist", by G. Taylor, of the Royal Botanic Gardens, Kew ; and J. Grant Roger has contributed a useful article on the "Conservation of the Scottish Flora".

Further evidence of the work of this distinguished and active botanical society has also been published (Trans., 37, Part 4 ; 1959). This is devoted entirely to various aspects of Scottish botany. Thus there are floristic studies of a number of different regions, sometimes combined with geological observations. D. Ratcliffe has contributed an article on the "Habitat of Koenigia islandica" ; and D. G. Downie on "Rhizoctonia solani and Orehid Seed". There is a special cryptogamic section by D. M. Henderson and an alpine section by $D$. Grant Roger. There is also a useful genoral article dealing with botanical research in Scotland. This gives a brief account of the activities of the main research institutes, including those devoted to marine biology and nature conservancy, but it is not concerned with university departments of botany. 